\title{
PENGGUNAAN NOMINA KYOKU DAN UTA PADA KOLOM KOMENTAR YOUTUBE
}

\author{
Yeni $^{1}$, G.S. Hermawan ${ }^{2}$ \\ 1,2Jurusan Bahasa Asing, Universitas Pendidkan Ganesha, Singaraja \\ e-mail: yeni@undiksha.ac.id, satya.hermawan@undiksha.ac.id
}

\begin{abstract}
Abstrak
Penelitian ini memperlihatkan penggunaan kata bersinonim, atau memiliki persamaan makna. Kata yang dipilih adalah kyoku dan uta, yang masing-masing kata merujuk pada pemaknaan tentang lagu. Bagi pembelajar bahasa Jepang kata uta lebih dikenal untuk menunjuk ke pemaknaan lagu, dan ongaku untuk menunjuk ke pemaknaan musik. Penelitian ini akan memperlihatkan bahwa dalam penggunaannya kata uta dapat digantikan dengan kata kyoku, yang secara umum menunjuk pada pemaknaan lagu. Tetapi kyoku memperlihatkan makna yang lebih spesifik. Data diambil dari kolom komentar youtube tehadap lagu-lagu populer Jepang. Dipilih tiga lagu yang berada di tiga besar tangga lagu Oricon Chart, yaitu: Gomen ne Finger Crossed (Nogizaka 46); Hitori ni Shinai yo (Kanjani 8), dan Pale Blue (Kenshi Yonezu).
\end{abstract}

Kata kunci: makna, kosakata, sinonim, kyoku, uta

\section{Abstract}

This study shows the use of words that are synonymous, or have the same meaning. The words chosen are Kyoku and Uta, each of which refers to the meaning of the song. For Japanese language learners, the word Uta is better known to refer to the meaning of a song, and Ongaku refers to the meaning of music. This study will show that in its use the word Uta can be replaced with the word Kyoku, which generally refers to the meaning of the song. But Kyoku shows a more specific meaning. The data is taken from the YouTube comments on popular Japanese songs. Three songs were selected that are in the top three of the Oricon Chart, namely: Gomen ne Finger Crossed (Nogizaka 46); Hitori ni Shinai yo (Kanjani 8), and Pale Blue (Kenshi Yonezu).

Keywords : meaning, words, synonym, kyoku, uta

\section{Pendahuluan}

Makna kata yang identik atau sama disebut dengan sinonim. Sinonim tidak hanya berfokus pada makna yang sama, tetapi juga melihat beda penggunaannya. Untuk hal tersebut Schreyer (1978) melakukan penelitian tentang definisi sinonim dilihat dari konteks atau pemakaiannya. Schreyer (1978) membagi menjadi lima definisi, pada definisi pertama secara semantik pemaknaan sinonim tentu saja adalah kesamaan makna. Akan tetapi terdapat sedikit alasan untuk mempertimbangkan kesamaan makna terbatas pada tingkatan kata saja, tidak merujuk lebih jauh pada tingkatan kalimat atau teks. Sintagma, kalimat, dan bahkan teks yang lebih pendek dan lebih panjang dapat dikatakan satu dengan yang lainnya memilki kemiripan makna, sehingga sifat sinonim pada kata bisa dikatakan terdapat pula sintagma atau kalimat. Dengan ini maka wilayah sintaksis dapat masuk ke dalamnya. Untuk itu diperlukanlah definisi kedua.

Lebih lanjut, Schreyer (1978) memberikan definisi kedua, yaitu sinonimitas atau sifat sinonim tersebut tidak terbatas pada kata saja, tetapi juga pada ekspresi. Di sini argumentasi pun lahir, bagaimana cara melihat sinonimitas pada ekspresi? Karena bagaimana pun sinonim selalu berada di bawah ilmu makna atau semantik. Definisi yang dikemukan oleh Schreyer (1978) hanya terbatas pada metode, mencari tahu jika memiliki sinonimitas atau tidak.

Hal yang dapat ditekankan pada penelitian Schreyer (1978) adalah sinonimitas konteks berada di wilayah metalinguistik, menyiratkan dua kata sinonim A dan B jika ditempatkan pada satu ekspresi dapat terlihat perbedaan penggunaannya. Sehingga dapat ditentukan sebenarnya A itu berbeda dengan B. Sehingga sejatinya kata yang bersinonim tersebut, 
secara ekspresif dalam penggunaannya merupakan keanekaragaman kosakata pada bahasa.

Konsep yang diberikan oleh Schreyer pada tahun 1976 (terdapat revisi dan tambahan referensi pada artikel terbaru pada 1978) menjadi dasar berpikir bahwa penggunaan kata bersinonim dapat menunjukan kemampuan dalam memproduksi kalimat atau ujaran. Hal ini dapat diterapkan pada bidang pendidikan. Penelitian yang menerapkan hal tersebut seperti penelitian dari Webb (2007) yang mengkaji efek sinonim pada pengetahuan akan kosakata terhadap 84 siswa Jepang yang belajar bahasa Inggris.

Pada penelitian Webb (2007) digunakan sepuluh tes yang mengukur lima aspek pengetahuan kata untuk menilai pembelajaran. Seperti : ortografi; asosiasi paradigmatik; asosiasi sintaksis; makna dan bentuk; dan fungsi gramatikal. Kedua tes reseptif dan produktif digunakan untuk mengukur setiap aspek pengetahuan kosa kata. Para peserta menemukan kata-kata target dalam dua kondisi pembelajaran: gloss kalimat dan pasangan kata. Dari penelitiannya ditemukan bahwa bahwa peserta didik memiliki skor yang lebih tinggi secara signifikan untuk kata-kata yang yang dipelajari dengan mencari sinonimnya. Hal ini menunjukan bahwa dalam mempelajari kosakata mencari padanan kata membuat pemahaman kosakata lebih baik dibandingkan dengan hanya mempelajari kosakata tanpa mencari sinonimnya.

Selain dalam pendidikan, konsep yang diberikan Schreyer (1978) juga dapat dilihat pada penelitian analisis wacana, untuk mengeksplorasi tentang keutuhan makna sebuah wacana atau pun penggunaan pilihan kata untuk sebuah ekspresi dalam wacana. Terkait dengan hal ini, terdapat penelitian dari Bader dan Badarneh (2018) yang menjelaskan penggunaan sinonim dalam pidato parlemen di Yordania.

Penelitian Bader dan Badarneh (2018) ini menyelidiki penggunaan sinonim dalam pidato Parlemen di Yordania dan menjelaskannya fungsi utamanya Penelitian ini menemukan lebih dari 270 sinonim yang digunakan pada dua puluh narasi pidato, yang menjadi sumber data penelitian ini. Hasil dari kajian mengungkapkan bahwa fungsi sinonim yang paling penting yang digunakan oleh politisi termasuk penekanan dan penegasan, mengungkapkan emosi dan perasaan, pujian dan penghargaan, klarifikasi, kritik, ketidakpuasan, dan lain-lain. Banyak pengunaan sinonim tidak memiliki fungsi ekspresif yang sangat spesifik, dan dianggap berlebihan.

Dari tinjauan pustaka yang disebutkan sebelumnya, diketahui bahwa sinonimitas sebuah kata, dapat ditilik lebih jauh keragaman pengungganaannya jika dikaitkan dengan konteks, atau dibentuk berdasarkan sebuah ekspresi. Untuk itu penelitian ini akan menunjukan penggunaan dua kata yang memilki makna identik, yaitu kyoku dan uta. Pemilihan sepasang kata ini disebabkan bahwa pembelajar bahasa Jepang diperkenalkan kata uta untuk memperlihatkan makna lagu. Kata tersebut merupakan nomina, sedangkan untuk kata yang menunjukan aktifitas bernyanyi adalah verba utau. Kata ini selalu dijelaskan bersama nomina ongaku yang bermakna musik, untuk menunjukan perbedaan penggunaannya. Akan tetapi pada penggunaan di media sosial, seperti twitter, dan youtube, ditemukan kecenderungan penggunaan kata kyoku lebih sering digunakan alih-alih menggunakan kata uta untuk menunjuk makna 'lagu'. Terlihat pula kecenderungan atau dugaan bahwa penggunaan uta lebih banyak digunakan oleh pembelajar bahasa Jepang (bahasa Jepang sebagai bahasa asing), dan penutur asli (native speaker) cenderung menggunakan kata kyoku. Kecenderungan dan dugaan itu tentunya perlu dikaji lebih lanjut melalui sebuah penelitian. Pada penelitian ini hanya akan membahas permasalahan yang pertama, yaitu melihat penggunaan uta dan kyoku pada sebuah wacana atau teks di media sosial. Untuk permasalahan kedua, terkait tentang pengguna kedua kata tersebut (pembelajar bahasa Jepang atau penutur asli) tidak akan dibahas dalam penelitian ini.

\section{Semantik}

Semantik merupakan studi tentang cara-cara bahasa digunakan untuk mewakili makna. Lebih tepatnya, semantik bertujuan untuk menjelaskan proses makna literal dikodekan dan diterjemahkan secara linguistik oleh penutur dan mitra tutur. Pendekatan lain untuk makna termasuk pragmatik, yang berkaitan dengan cara-cara makna disimpulkan 
dalam kaitannya dengan konteks, dan semiotika, yang merupakan studi yang lebih umum tentang cara manusia dalam menafsirkan tanda-tanda linguistik dan nonlinguistik (Stringer, 2019).

Lalu, Stringer (2019) juga menjelaskan bahwa, dibandingkan dengan pragmatik dan semiotika, semantik memiliki cakupan penyelidikan yang lebih sempit karena membatasi perhatiannya pada aspek makna linguistik. Dalam semantik, terdapat berbagai pendekatan teoretis, termasuk semantik formal, yang menggunakan logika proposisional untuk menangkap hubungan antara ekspresi linguistik dan hal-hal yang dirujuknya, dan semantik kognitif, yang melihat makna dalam bahasa muncul dari prinsip-prinsip kognitif umum.

Melihat pemaknaan sebagai satu bentuk ekspresi, dapat ditunjukan melalui cara bahasa itu diperoleh. Individu-individu dalam bahasa melibatkan tindakan ekspresi. Ekspresi adalah tindakan menuangkan pikiran ke dalam bentuk verbal, yang melibatkan penyandian atau penciptaan teks atau ucapan. Individu terlibat dalam bahasa baik sebagai pembicara/pendengar dan penulis/pembaca, dan keterlibatan ini melibatkan tindakan ekspresi dan komunikasi. Tindak ekspresi adalah ranah kreativitas linguistik, yang bukan sekadar produksi mekanis dari suatu ujaran menurut aturan tata bahasa dari kode linguistik, tetapi juga penciptaan teks yang unik dengan makna individual (Williams, 1993).

\section{Sinonim}

Sinonim secara tradisional didefinisikan sebagai kesamaan makna atau hubungan semantik dari dua kata atau lebih yang memiliki arti yang sama atau serupa. Akibatnya, beberapa literatur biasanya mendefinisikan sinonim sebagai kata-kata dengan lisan yang sama dan makna yang sama. Definisi yang lebih baru dan lebih tepat menghindari penggunaan istilah kata dan leksem, karena sinonim juga terjadi di antara ekspresi gabungan. Sebaliknya mereka menggunakan unit leksikal atau ekspresi karena mereka mencakup kata tunggal dan unit multi-kata, yang mencakup ekspresi idiomatik, idiom, frasa verba, istilah majemuk dan sebagainya (Broz dan Glavan, 2011).

Stringer (2019) menjelaskan sinonim dalam beberapa hal kebalikan dari homonimi: sinonim adalah kata-kata dengan fonologi yang berbeda tetapi dengan arti yang sama, atau kira-kira sama. Namun, jarang ada dua item leksikal yang benar-benar dapat dipertukarkan. Perbedaan antara 'referensi' dan 'pengertian' berguna untuk digunakan dalam kasus ini, karena lebih sering, sinonim yang diduga seringkali merupakan dua pengertian yang terpisah dengan referensi yang sama. Dari penjelasan Stringer memperlihatkan beberapa pasangan kata yang dapat saling menggantikan pada satu konteks, tapi tidak bisa saling menggantikan di konteks yang lain.

Dari penjelasan tentang semantik sebagai studi yang berkaitan tentang makna, yang tidak hanya berkorelasi pada kata saja, tetapi juga pada bagian ekspresi. Berlanjut tentang ekspresi berarti terdapat berbagai pilihan cara, dan penggunaan sinonimitas baik pada kata, teks, maupun lisan termasuk di dalamnya. Sinonim tidak saja berarti sama makna, melainkan pula digunakan pada referensi, dan konteks yang sesuai.

\section{Metode}

Metode penelitian ini adalah deskriptif kualitatif. Data dikumpulkan dari komentarkomentar pada Youtube. Video youtube yang dipilih merupakan tiga besar Oricon Chart. Musik video yang dipilih adalah Gomen ne Finger Crossed (Nogizaka 46); Hitori ni Shinai yo (Kanjani 8), dan Pale Blue (Kenshi Yonezu). Klasifikasi data berdasarkan adanya penggunaan kata kyoku dan uta. Analisis dilakukan dengan pendekatan semantik, dengan melihat penggunaan kedua kata tersebut pada teks.

\section{Hasil dan Pembahasan}

Makna Leksikal Kyoku dan Uta akan diperlihatkan terlebih dahulu sebagai pijakan awal. Makna leksikal diperoleh dari Kokugo Jiten online (dictionary.goo.ne.jp). 
Kyoku (曲)

1. 楽曲の調子。節 (ふし)。「詞に曲をつける」

Gakkyoku no choushi. fushi. [shi ni kyoku o tsukeru]

Nada lagu. Melodi. Menempatkan lirik pada lagu

2. 音楽の作品。能・狂言や舞踊などにもいう。「バッ八の曲を演奏する」

Ongaku no sakuhin. Nou, kyougen, ya buyou nado ni mo iu. [bahha no kyoku o ensou suru]

Bagian dari musik. Juga direferensikan untuk Noh, Kyogen, dan tarian budaya. [Memainkan Lagu Bach's]

Dari enam makna leksikal pada kokugo jiten (dictionary.goo.ne.jp), terdapat dua makna kata nomina kyoku yang merujuk pada lagu dan musik. Selanjutnya akan diperlihatkan makna leksikal dari nomina uta.

\section{Uta (歌)}

1. 拍子と節をつけて歌う言葉の総称。また、それを歌うこと。神楽歌・催馬楽 (さいばら)・今様(いまよ

う) から、現今の唱歌・民謡・歌謡曲などまで種類が多い。

Hyoushi to setsu o tsukete utau kotoba no soushou. Mata, sore o utau koto. Kagura uta, saibara, imayou kara, genkon no shouka, min'you, kayoukyoku nado made shurui ga ooi.

Istilah umum dalam bernyanyi dengan tempo dan melodi. Juga, merujuk pada kegiatan bernyanyi. Dapat direferensikan semua lagu dari lagu Kagura, Saibara, dan Imayou, hingga lagu masa kini, lagu daerah, lagu populer, dan lainnya

2. (唄) 三味線を伴奏とする「うたいもの」の称。長唄・端唄 (はうた) ・小唄・地唄など。 (uta) shamisen o bansou suru [utai mono] no shou. Nagauta, hauta, kouta, jiuta nado.

(lagu) Penyebutan untuk 'lagu-lagu' yang diiringi shamisen. Seperti Nagauta, Hauta, Kouta, Jiuta, dan lainnya.

Dari empat makna leksikal pada kokugo jiten (dictionary.goo.ne.jp), terdapat dua makna nomina uta yang merujuk pada lagu dan musik. Makna lainnya merujuk kepada puisi tradisional Jepang seperti Tanka, Chouka, dan lainnya. Kemudian dari hasil pemaknaan leksikal ditemukan bahwa untuk nomina uta terdapat dua huruf kanji yang merujuknya, yaitu 歌 dan 唄. Nomina uta yang dituliskan dengan huruf kanji 歌 menunjukan lagu secara umum, baik tradisional maupun modern. Sedangkan nomina uta yang dituliskan dengan huruf kanji 唄 menunjuk lagu tradisional Jepang, yang dinyanyikan dan diiringi dengan petikan shamisen. Contoh yang diberikan pada kamus seperti Nagauta, Hauta, dan lain sebagainya.

Kemudian, dari membandingkan kedua makna leksikal tersebut, nomina uta memilki makna lebih umum. Sedangkan kyoku menunjukan makna yang lebih spesifik, seperti merujuk pada beat lagu, melodi, tempo, dan lainnya. Sehingga dari hasil membandingkan makna leksikal ini diketahui nomina uta digunakan untuk mengekpresikan lagu secara umum, sedangkan kyoku digunakan untuk mengekpresikan bagian-bagian dari lagu tersebut.

Berikut merupakan hasil dari penelitian ini, terdapat tiga hasil yang diperoleh dari menganalisis komentar pada video musik Gomen ne Finger Crossed (Nogizaka 46); Hitori ni Shinai yo (Kanjani 8), dan Pale Blue (Kenshi Yonezu) di youtube.

1. Dalam mengepresikan 'lagu' lebih banyak digunakan nomina kyoku dibandingkan dengan uta.

2. Uta lebih banyak digunakan dalam bentuk kata yang menjadi referensinya, seperti utau '歌う' yang merupakan verba, dan kashi '歌詞' yang merujuk pada makna lirik.

3. Nomina uta dan kyoku digunakan merepresentasikan seluruh lagu.

Kemudian, terdapat sepuluh contoh data yang akan dibahas untuk menjelaskan tiga hasil penelitian tersebut. 
Data 1.

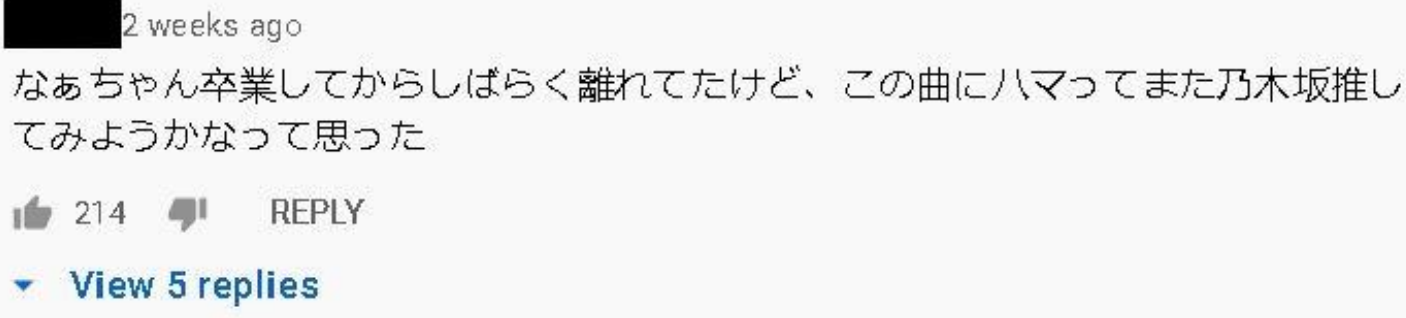

Gambar 1. Komentar pada lagu Gomen ne Finger Crossed 1

Pada data 1 menunjukan komentar seseorang yang sudah lama tidak mendengar lagu dari Nogizaka 46 setelah salah membernya lulus, akan tetapi ia kembali melihat Nogizaka 46 setelah tertarik dengan lagu barunya yaitu Gomen ne Finger Crossed. Dari ekspresi ini dapat dilihat jika nomina kyoku merujuk pada lagu secara bagian, dari melodi, lirik, dan irama yang membuat seseorang kembali menyukai grup idol yang pernah dilupakannya. Dalam komentar tertulis : "Setelah Naa Chan lulus (aku) pergi sebentar, tetapi tertarik dengan lagu ini membuat berpikir sepertinya akan ke Nogizaka lagi".

Pada komentar tersebut, dapat dikatakan melodi atau beat lagu tersebut yang membuat orang tergila-gila sehingga digunakanlah nomina kyoku. Jadi yang membuat si komentar tertarik dengan lagu tersebut pertama kalinya adalah salah satu bagian dari lagu, tidaklah bermakna lagu secara utuh.

Data 2.

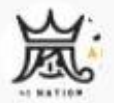

1 week ago

関ジャ二の男くさい曲、面白い曲も大好きだけど、この曲は優しくてあたたかく

て、関ジャ二の魅力がまた $1 つ$ 増えた！ドラマにぴつたりな主題歌でした！！

\section{9 q REPLY}

Gambar 2. Komentar pada lagu Hitori ni Shinai yo 1

Pada data 2 memperlihatkan penggunaan nomina kyoku, yang merujuk pada pemaknaan lagu secara khusus yang dinyanyikan atau dibuat oleh seseorang. Komentar tersebut memperlihatkan lagu dinyanyikan Kanjani 8 itu berbeda dengan lagu-lagu yang selama ini dinyanyikan, perbedaannya pada nuansa lagunya. Akan tetapi si komentar tetap menyukai perbedaan ini. Dituliskan : "(saya) suka lagu Kanjani yang maskulin atau lagu Kanjani yang menyenangkan, tetapi lagu ini begitu tenang dan hangat, pesona Kanjani meningkat satu lagi! Cocok untuk theme song dorama!!". Di sini terlihat dengan jelas bahwa nomina kyoku digunakan untuk merujuk lagu-lagu milik Kanjani, tidak merujuk pada lagu secara umum. Padanan yang sesuai adalah track, untuk menggambarkan spesifik bagian dari karya seseorang. Penjelasan yang sama terdapat pada data 3.

Data 3.

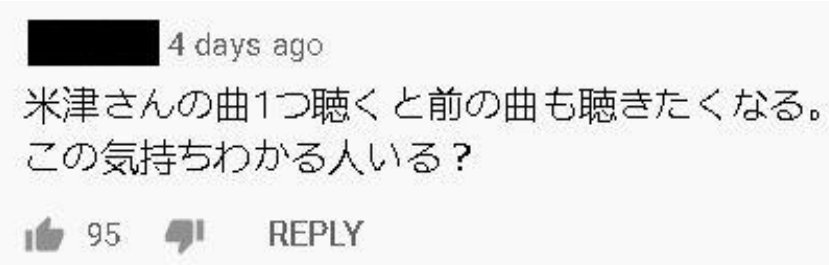

Gambar 3. Komentar pada lagu Pale Blue 1

Pada data 3 memperlihatkan penggunaan nomina kyoku, yang merujuk pada pemaknaan lagu secara khusus yang dinyanyikan atau dibuat oleh seseorang, kondisi yang 
sama seperti data 2. Komentar tersebut memuji lagu milik Yonezu. Dituliskan : "jika pertama kali mendengar lagu milik Yonezu, maka orang yang mendengarnya akan tertarik untuk mendengar lagu-lagu lain milik Yonezu. Adakah orang yang mengerti dengan perasaan ini?". Di sini pemaknaan merujuk pada keseluruhan karya yang dinyanyikan oleh Yonezu.

Padanan yang tepat di sini adalah track, yang dalam bahasa Indonesia sendiri padanan tersebut tidak ada, sehingga tetap saja disamakan dengan lagu. Sedangkan uta pada data ini tidak bisa menggantikan nomina kyoku, karena bermakna lagu secara umum atau padanan tepatnya adalah song. Jadi ketika melihat 'lagu' secara umum maka menggunakan nomina uta, sedangkan ketika melihat lagu sebagai bagian karya seseorang atau bagian track dari album, atau pun track pada sebuah single, digunakan nomina kyoku.

Data 4.

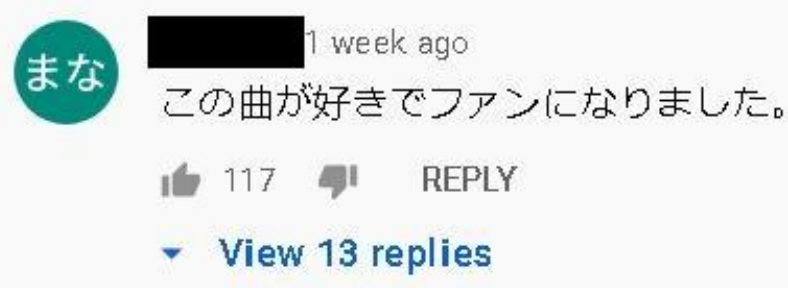

\section{Gambar 4. Komentar pada lagu Gomen ne Finger Crossed 2}

Data 4 menunjukan contoh penggunaan nomina kyoku yang dapat digantikan dengan uta. Pada komentar tertulis : "Suka dengan lagu ini, dan menjadi fans". Pada komentar tersebut memperlihatkan seseorang yang menjadi penggemar setelah mendengar lagu yang dikomentari. Nomina kyoku dapat digantikan dengan uta, pada komentar ini dan menjadi sebagai berikut.

この歌が好きでファンになりました。

Kono uta ga suki de fan ni narimashita.

Suka dengan lagu ini, dan menjadi fans

Terlihat jika baik nomina kyoku dan nomina uta dapat menggantikan dengan baik satu dengan lainnya. Pada kasus data 4 ini dapat dikatakan nomina uta dan kyoku bersinonim. Lalu, nomina uta dan kyoku dapat saling menggantikan ketika kyoku merepresentasikan 'lagu' secara utuh, bukan menjadi bagian dari sebuah 'lagu'.

Data 5.

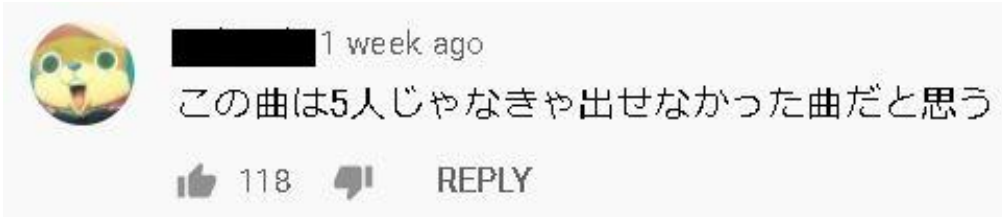

Gambar 5. Komentar pada lagu Hitori ni Shinai yo 2

Pada data 5 memperlihatkan komentar tentang pujian seperti "Bagaimana bisa lagu ini hanya dinyanyikan oleh lima orang?". Secara teks berarti bagian-bagian dari lagu ini seharusnya dinyanyikan oleh lima orang tidak bisa kurang dari jumlah tersebut untuk menghasilkan karya yang didengarkan. Hal ini menunjukan bahwa nomina kyoku memperlihatkan bagian-bagian dari lagu yang seharusnya dinyanyikan oleh lima orang. Representasi lagu di sini tidak merujuk lagu secara utuh melainkan bagian dari lagu tersebut. Bagian-bagian dari lagu dapat berupa : nada, melodi, tune, beat, tempo, lirik, dan sebagainya. Oleh karena merujuk pada hal tersebutlah nomina kyoku digunakan. Pada komentar dituliskan : "(saya) pikir lagu ini adalah lagu yang tidak bisa dirilis tanpa lima orang".

Sehingga pemaknaan 'lagu' pada komentar ini merujuk pada bagian-bagian dari lagu. Data 6 dan data 7 mendukung penjelasan dari analisa ini. 
Data 6.

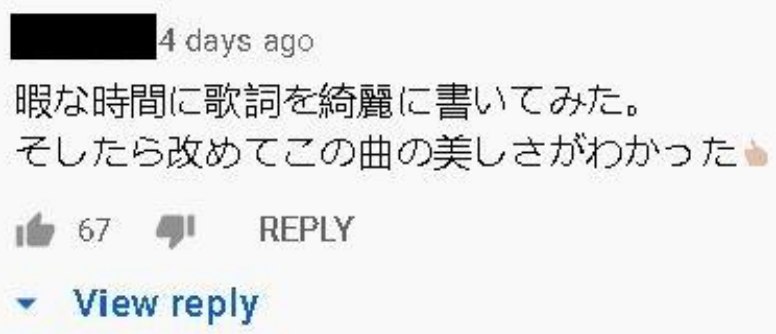

Gambar 6. Komentar pada lagu Pale Blue 2

Pada data 6 di sini nomina kyoku disandingkan dengan nomina kashi yang bermakna lirik, sehingga nomina kyoku di sini mengekspresikan bagian lagu secara spesifik yaitu lirik dan melodi. Nomina kashi sendiri merupakan kata yang dibentuk dari huruf kanji 歌 -uta(lagu) dan 詞 -shi- (puisi, kata-kata); yang bermakna lirik lagu. Komentar pada data 6 ditulis sebagai berikut: " mencoba menulis lirik yang indah di waktu senggang. Kemudian (aku) menyadari akan keindahan lagu ini". Orang yang berkomentar tersebut memahami jika lirik dan melodi yang indah akan menghasilkan lagu yang indah pula.

Sehingga dari data 6 ini dapat dilihat bahwa nomina kyoku juga dapat menunjukan bagian spesifik dari lagu yaitu lirik dan melodi. Menunjukan bagian spesifik dari lagu ini tidak bisa ditunjukan oleh nomina uta karena nomina tersebut menunjukan 'lagu' secara utuh. Data 6 ini menunjukan bahwa nomina kyoku tidak sama dengan nomina uta, tetapi nomina kyoku sama dengan nomina kashi. Hal ini disebabkan karena baik kyoku dan kashi merupakan meronym dari uta. Hal ini akan dijelaskan pada data 7.

Data 7.

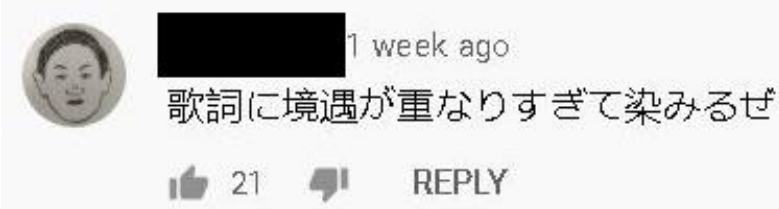

Gambar 7. Komentar pada lagu Gomen ne Finger Crossed 3

Pada data 7 memperlihatkan komentar seseorang yang terkesan dengan lirik lagu yang sesuai dengan keadaan sekitar. Pada data 7 tidak diperlihatkan nomina uta, tetapi kosakata direferensikan dari nomina uta. Nomina kashi bermakna lirik lagu, merujuk pada pemaknaan spesifik dari bagian lagu. Menurut Xian-mo (2007) hal ini disebut dengan hubungan bagian-keseluruhan. Seperti contoh yang diberikan Xian-mo dengan kata utama 'badan' maka hubungan bagian-keseluruhan-nya adalah kaki, tangan, dan lainnya. Jika lagu, maka bagiannya adalah lirik, nada, melodi, dan lainnya. Dalam semantik hubungan makna antara bagian dan keseluruhannya disebut dengan Meronymy (Ittoo dan Bouma, 2009; Klein, 2000). Sedangkan bagian keseluruhannya disebut dengan Holonymy (Ittoo dan Bouma, 2009). Dalam kasus data 7 ini, maka lirik lagu (歌詞) merupakan meronym dari lagu (歌). Dengan kata lain lagu (歌) merupakan holonym dari lirik lagu (歌詞), melody (メロディー・曲調), tune (チューン・曲), dan sebagainya. Dari sini bisa dilihat bahwa hubungan antara uta dan kyoku bukan lagi hubungan kata bersinonim, melainkan hubungan holonym-meronym. Nomina uta merupakan holonym dari kyoku, sedangkan kyoku merupakan meronym dari uta.

Dikaitkan dengan penjelasan pada data 6 , maka nomina uta jika merujuk pada lirik lagu digunakan nomina kashi, sedangkan kyoku dapat mereferensikan hal tersebut dilihat dari konteksnya. 
Data 8.

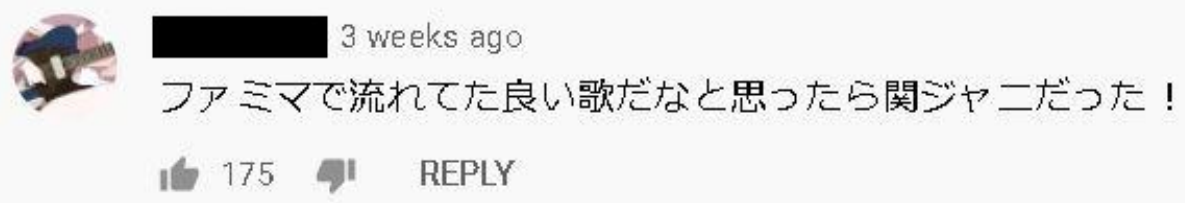

Gambar 8. Komentar pada lagu Hitori ni Shinai yo 3

Data 8 memperlihatkan penggunaan nomina uta. Nomina uta digunakan karena mengacu pada makna umum kata 'lagu'. Si komentar tidak mengetahui bahwa lagu yang didengar merupakan lagu milik Kanjani. Oleh karenanya konteksnya adalah menyebutkan lagu secara umum maka digunakanlah nomina uta. Dalam komentar ditulis : "(saya) pikir lagu yang bagus yang diputar di Family Mart, (ternyata itu lagu) Kanjani”.

Sesuai dengan makna leksikal pada kokugo jiten di bagian sebelumnya, nomina uta secara leksikal merujuk kepada pemaknaan lagu secara umum. Sehingga data 8 ini sesuai dengan hal tersebut.

Data 9.

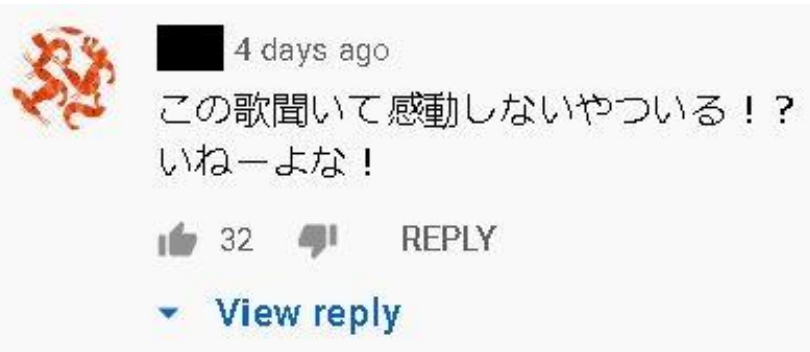

Gambar 9. Komentar pada lagu Pale Blue 3

Data 9 memperlihatkan penggunaan nomina uta yang merujuk pada penggunaan secara umum. Komentar diekspresikan dalam bentuk satire untuk memuji lagu yang dikomentari. Ditulis pada komentar: "Terdapat orang tidak terkesan ketika mendengar lagu ini!? Maaf saja!" Pemilihan nomina uta dikarenakan menunjukan makna lagu secara keseluruhan. Komentar ini dibuat untuk menyindir orang-orang yang tidak bisa merasakan keindahan dari keseluruhan lagu tersebut.

Dari data 9 dapat dilihat bahwa nomina uta digunakan untuk menunjukan lagu secara utuh, tidak spesifik pada salah satu bagian lagu saja. Hal ini sesuai pula dengan analisa data 6 dan data 7 sebelumnya. Jadi dari sini dapat dilihat bahwa ketika kita melihat sebuah lagu secara utuh, maka penggunaan nomina uta yang digunakan.

Data 10.

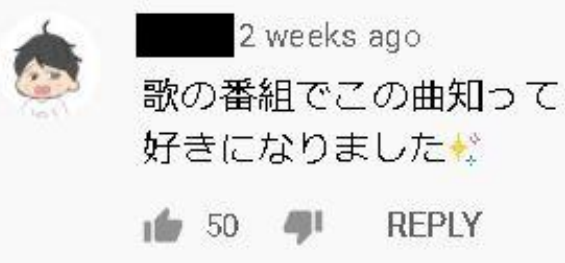

\section{Gambar 10. Komentar pada lagu Hitori ni Shinai yo 3}

Pada data 10 memperlihatkan dengan baik penggunaan antara nomina uta dan kyoku. Data 10 menunjukan bahwa nomina uta digunakan untuk memperlihatkan makna lagu secara umum, sedangkan nomina kyoku digunakan untuk merujuk pada lagu secara khusus (atau karya seseorang). Nomina uta digunakan untuk menerangkan inti frasa nomina bangumi (acara). Dikarenakan fungsinya tersebut, maka jelas bahwa nomina uta lebih 
banyak digunakan untuk menunjuk lagu-lagu secara umum. Sedangkan pada komentar nomina kyoku digunakan untuk menunjuk lagu yang dikomentari (secara spesifik).

Dari data 10 diketahui bahwa sinonim total itu jarang terjadi, atau adanya makna yang tepat serupa adalah kecil untuk dimungkinkan. Hal ini sesuai dengan hal yang diungkapkan Dolezal (2013), dapat dikatakan bahwa sinonim mutlak jarang terjadi, dan hanya ditemukan mengenai persepsi akan sinonim. Sehingga diskusi akan berlanjut tentang makna yang sebagian sama atau makna yang dekat dengan makna bandingannya.

Hasil analisa terhadap data (10 data sebagai perwakilan contoh) ditemukan bahwa penggunaan nomina uta pada kolom komentar di youtube digunakan untuk menunjuk makna 'lagu' secara umum. Sedangkan nomina kyoku digunakan untuk menunjuk makna 'lagu' secara spesifik (karya seseorang, atau bagian dari lagu secara utuh).

\section{Simpulan dan Saran}

Simpulan yang diperoleh adalah nomina uta merepresentasikan makna 'lagu' secara umum, dan makna lagu secara utuh. Sedangkan nomina 'kyoku' merepresentasikan makna 'lagu' secara spesifik, dan makna merujuk pada bagian-bagian lagu seperti melodi, irama, beat, dan sebagainya. Realasi makna antara uta dan kyoku lebih terlihat sebagai hubungan holonym-meronym, dibandingkan hubungan sinonim. Walaupun data juga memperlihatkan terdapat penggunaan kata yang dapat saling menggantikan, tetapi tetap memiliki perbedaan makna secara kontekstual.

\section{Daftar Pustaka}

Bader, Y., Badarneh, S. 2018. The Use of Synonyms in Parliementary Speeches in Jordan. AWEJ for Translation \& Literary Studies, 2 (3): 43-67

Broz, V., Glavan, M. 2011. Synonymy in Idiomatic Expressions. SRAZ L IV: 45-70

Dolezal, F. 2013. Synonymy and Sameness of Meaning: An Introductory Note. International Journal of Lexicography, Vol 26, No 3: 255-259

Ittoo, A., Bouma, G. 2009. Semantics Selectional Restrictions for Disambiguating Meronymy Relations. B. Plank., E.T. Kim Sang., \& T. Van de Cruys (editor). The 19th Meeting of Computational Linguistics: 83-98 (prosiding)

Klei, H.E.M. 2000. Meronymy or Part-Whole Relations in Indigenous Languages of Lowland South America. H. Van der Voort., \& S. Van De Kerke (editor). Indigeneous Languages of Lowland South America [Indigenous of Latin America 1] : 83-98. Leiden : School of Asian, African, and Amerindian Studies (CNWS)

Matsumura, A. 2021. 国語辞書 : デジタル大辞泉 (kokugo jiten : dejitaru daijisen). Ikegami, A., Hiroshi, K., dkk (editor). Shogakukan. Tersedia pada goo 辞書 - 国語・英語・四字熟 語のオンライン辞書.

Oricon Chart. 2021. 月間シングルランキング : 2021 年 06 月度 (gekkan shinguru rankingu : 2021 nen 06 gatsu dou). Oricon News. Tersedia pada オリコン月間 シングルランキ ング 2021 年 06 月度| ORICON NEWS, diakses pada tanggal 1 Juli 2021.

Schreyer, R. 1978. Synonyms in Context. Working Papers in Language and Linguistics, 7: 821

Stringer, D. 2019. Lexical Semantics: Relativity and Transfer. Pada N.Erdogan.,\& M. Wei (editor). Applied Linguistics for Teachers od Culturally and Linguistically Diverse Learners, 180-203. IGI Global

Webb, S. 2007. The Effect of Synonymy on Second-language Vocabulary Learning. Reading in Foreign Language, 19 (2): 120-136 
Williams, J.R. 1993. Expression and Communication as Basic Linguistics Functions. Intercultural Communication Studies, III (1): 91-101

Xian-mo, Z. 2007. Semantics Relationships Between Contextual Synonym. US-China Education Review, Vol 4, No 9 (34): 33-37 